Hironori Iwasaki • Nobutaka Ota • Toshiaki Nakajima

Yasutomo Shinohara • Mina Kodaira - Mitsuko Kajita

Mitsuru Emi

\title{
Five novel single-nucleotide polymorphisms of human interferon gamma identified by sequencing the entire gene
}

\begin{abstract}
Interferon gamma (IFNG) plays important roles in the regulation of bone remodelling. We describe here six single-nucleotide polymorphisms (SNPs) in the IFNG gene, five of which are novel, and their allelic frequencies in the Japanese population, as determined by sequencing 48 alleles of the entire gene. Four of these polymorphisms were identified inside the third intron, at nucleotide (nt) positions 2459 (A/G), 2671 (T/C), 3177 (T/G), and 3273 (G/A). In exon 4, SNPs were identified at nt positions $5199(\mathrm{~A} / \mathrm{T})$ and $5272(\mathrm{~A} / \mathrm{G})$. These polymorphic sites will be useful for genetic studies of disorders that affect the inflammatory process or calcium metabolism.
\end{abstract}

Key words Interferon gamma $\cdot$ Single-nucleotide polymorphism - Japanese population - Inflammation - Calcium metabolism

\section{Introduction}

The reduction in bone mass per unit volume that is characteristic of osteoporosis is not accompanied by any qualitative abnormalities in mineral content or organic matrix. Therefore, in this disease, the rate of bone resorption must exceed that of bone formation, and, in fact, the rate of bone formation does tend to be lower than normal in patients with osteoporosis, especially in postmenopausal women. Among a large number of risk factors for the development of osteoporosis (Ershler et al. 1997), genetic variation, especially of genes whose products regulate bone formation or resorption, could influence the heterogeneity in bone mass observed within population samples.

H. Iwasaki $\cdot$ N. Ota $\cdot$ T. Nakajima $\cdot$ Y. Shinohara $\cdot$ M. Kodaira $\cdot$

M. Kajita $\cdot$ M. Emi $(\bowtie)$

Department of Molecular Biology, Institute of Gerontology, Nippon Medical School, 1-396 Kosugi-cho, Nakahara-ku, Kawasaki 211-8533, Japan

Tel. +81-44-733-5230; Fax +81-44-733-5192

e-mail:memi@nms.ac.jp
The process of bone remodeling involves complex interactions between the osteoclast, the primary bone-resorbing cell, and other cells in its microenvironment. These interactions can regulate bone resorption by affecting either the number of osteoclasts present at a given site, or the boneresorbing capacity of individual osteoclasts (Roodman 1993). One of the most likely candidates for determining bone mass is interferon gamma (IFNG), a molecule known to influence both osteoclasts and osteoblasts (Ershler et al. 1997). To investigate a possible relationship between osteoporosis and genetic variation at the human IFNG locus, we searched for single-nucleotide polymorphisms by sequencing the entire INFG gene in 48 chromosomes from the normal Japanese population.

\section{Subjects and methods}

Extraction of genomic DNA. Blood samples were obtained, with informed consent, from 24 healthy Japanese individuals. Genomic DNA was prepared from each sample according to procedures described previously (Emi et al. 1999).

Polymerase chain reaction (PCR) conditions and primers. PCR and sequencing primers were determined by analyzing the IFNG genomic sequence with DNAsis 3.0 software (Hitachi Software Engineering, Tokyo, Japan). The numbering of sequences was adjusted to conform to the RNA transcription-start site (A at the top of GenBank J00219 is now +1). Four pairs of PCR primers and sequencing primers were selected, at approximately 1500-bp intervals, with overlaps of about $200 \mathrm{bp}$. Each genomic DNA (20 ng) was used as a template for PCR in a 10- $\mu$ l reaction volume containing $10 \mathrm{mM}$ Tris $\mathrm{HCl}(\mathrm{pH} 8.3), 1.5 \mathrm{mM} \mathrm{MgCl}_{2}$, $50 \mathrm{mM} \mathrm{KCl}, 20 \mathrm{mM}$ of each dNTP, $1 \mu \mathrm{M}$ of each oligonucleotide primer, and 0.5 U Taq DNA Polymerase (Roche Molecular Biochemicals, Switzerland), as described previously (Tsukamoto et al. 1998; Watanabe et al. 1998). PCR amplification was performed with a Gene Amp PCR 9600 System (Perkin Elmer Cetus, Norwalk, CT, USA) under 
the following conditions: $94^{\circ} \mathrm{C}$ for $3 \mathrm{~min}, 72^{\circ} \mathrm{C}$ for $3 \mathrm{~min}$, then 5 cycles of $94^{\circ} \mathrm{C}$ for $30 \mathrm{~s}, 60^{\circ} \mathrm{C}$ for $30 \mathrm{~s}, 72^{\circ} \mathrm{C}$ for $90 \mathrm{~s}$, followed by 25 cycles of $94^{\circ} \mathrm{C}$ for $30 \mathrm{~s}, 58^{\circ} \mathrm{C}$ for $30 \mathrm{~s}$, and $72^{\circ} \mathrm{C}$ for $90 \mathrm{~s}$.

$D N A$ sequencing. After purification on affinity membranes, PCR products were subjected to cycle-sequencing (Tsukamoto and Emi 1998) with appropriate primers. All sequencing reactions were performed using the ABI dye terminator cycle-sequencing reaction kit (PE Biosystems, Tokyo, Japan). The samples were then resuspended in formamide, separated on an ABI 377 sequencer (PE Biosystems), and analyzed with the attached software. Differences among IFNG sequences from the 24 DNA samples were regarded as SNPs.

\section{Results and discussion}

The entire genomic structure of the IFNG gene was sequenced in all 48 alleles from 24 healthy Japanese individuals, and we found a total of six SNPs. The genomic structure and locations of confirmed SNP sites are shown in Fig. 1. Four of the six SNPs were intronic: an $\mathrm{A} / \mathrm{G}$ at nucleotide (nt) position 2459 , a $\mathrm{T} / \mathrm{C}$ at $\mathrm{nt}$ position 2671 , a $\mathrm{T} / \mathrm{G}$ at $\mathrm{nt}$ position 3177, and a G/A at nt position 3273 . The other two

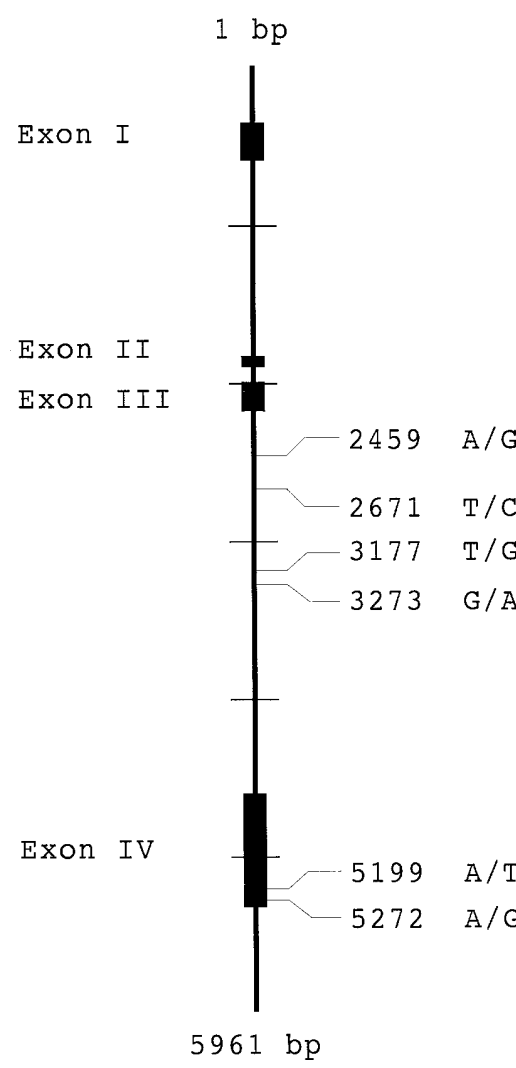

Fig. 1. Genomic structure and locations of single-nucleotide polymorphisms (SNPs) in the human IFNG gene. Black boxes represent coding regions (exons I-IV)
SNPs were present in exon 4, an $\mathrm{A} / \mathrm{T}$ substitution at $\mathrm{nt}$ position 5199 and an A/G substitution at nt position 5272 . Table 1 summarizes the SNPs and their allele frequencies in our population sample.

Of the six SNPs, five were novel; the T/C polymorphism at position 2671 was previously described in a Caucasian population (Bream et al. 2000). Although sequencing only 48 alleles might have limited the sensitivity of our experiments sufficiently to account for different results in the two studies, we suspect that differences in SNP distribution and allele frequencies in the IFNG gene must exist among different ethnic groups. We recently observed major differences between Japanese and Caucasian populations with regard to distribution and allele frequencies of SNPs in several other genes that are under investigation (manuscript in preparation).

Calcium levels in serum are kept in homeostasis through balanced interactions among calcitonin, parathyroid hormone, vitamin D, steroid hormones, and cytokines, and their receptors and modulators. IFNG is one of the most likely candidates for determining bone mass, because it is known to influence both osteoclasts and osteoblasts (Ershler et al. 1997). The powerful biological activities of IFNG are under strict control at both the transcriptional and the post-transcriptional levels (Cippitelli et al. 1995, 1996; Sica et al. 1997).

With respect to other cytokine genes, SNPs in cis-acting regions have been shown to alter transcriptional activity (Bailly et al. 1996; Gebhardt et al. 1999) and/or to be associated with the expression of specific phenotypes (Pociot et al. 1992; Rosenwasser and Borish 1997). For instance, in the IFNG promoter of the Albino Oxford (AO) rat, a singlebase insertion results in disruption of a consensus binding site for E4F1 transcription factor that coincides with a significantly decreased capacity to produce IFNG protein (Pravica et al. 1997). In light of recent progress in the understanding of the biological functions of INFG, the polymorphic sites characterized in the present study will serve as useful markers for examining the potential role of IFNG in bone metabolism and the pathogenesis of osteoporosis in Japanese patients

Acknowledgments This work was supported in part by special grants for Strategic Advanced Research on "Cancer" and "Genome Science" from the Ministry of Education, Science, Sports, and Culture of Japan; by a Research Grant from the Ministry of Health and Welfare of Japan; and by a Research for the Future Program Grant of The Japan Society for the Promotion of Science.

Table 1. Polymorphisms in the human $I F N G$ gene in the Japanese population

\begin{tabular}{llll}
\hline Gene region & Position & Nomenclature & Frequency \\
\hline Intron 3 & 2459 & $2459 \mathrm{~A} / \mathrm{G}$ & $\mathrm{A}(0.53), \mathrm{G}(0.47)$ \\
Intron 3 & $2671^{\mathrm{a}}$ & $2671 \mathrm{~T} / \mathrm{C}$ & $\mathrm{T}(0.42), \mathrm{C}(0.58)$ \\
Intron 3 & 3177 & $3177 \mathrm{~T} / \mathrm{G}$ & $\mathrm{T}(0.98), \mathrm{G}(0.02)$ \\
Intron 3 & 3273 & $3273 \mathrm{G} / \mathrm{A}$ & $\mathrm{G}(0.98), \mathrm{A}(0.02)$ \\
Exon 4 & 5199 & $5199 \mathrm{~A} / \mathrm{T}$ & $\mathrm{A}(0.05), \mathrm{T}(0.95)$ \\
Exon 4 & 5272 & $5272 \mathrm{~A} / \mathrm{G}$ & $\mathrm{A}(0.98), \mathrm{G}(0.02)$
\end{tabular}

${ }^{a}$ Also identified by Bream et al. (2000) in Caucasians 


\section{References}

Bailly S, Israel N, Fay M, Gougerot-Pocidalo MA, Duff GW (1996) An intronic polymorphic repeat sequence modulates interleukin-1 alpha gene regulation. Mol Immunol 33:999-1006

Bream JH, Carrington M, O'Toole S, Dean M, Gerrard B, Shin HD, Kosack D, Modi W, Young HA, Smith MW (2000) Polymorphisms of the human $I F N G$ gene noncoding regions. Immunogenetics 51:50-58

Cippitelli M, Sica A, Viggiano V, Ye J, Ghosh P, Birrer MJ, Young HA (1995) Negative transcriptional regulation of the interferon-gamma promoter by glucocorticoids and dominant negative mutants of cJun. J Biol Chem 270:12548-12556

Cippitelli M, Ye J, Viggiano V, Sica A, Ghosh P, Gulino A, Santoni A, Young HA (1996) Retinoic acid-induced transcriptional modulation of the human interferon-gamma promoter. J Biol Chem 271:2678326793

Emi M, Keicho N, Tokunaga K, Katsumata H, Souma S, Nakata K, Taguchi K, Ohishi N, Azuma A, Kudoh S (1999) Association of diffuse panbronchiolitis with microsatellite polymorphism at the human interleukin 8 (IL-8) locus. J Hum Genet 44:169-172

Ershler WB, Harman SM, Keller ET (1997) Immunologic aspects of osteoporosis. Dev Comp Immunol 21:487-499
Gebhardt F, Zanker KS, Brandt B (1999) Modulation of epidermal growth factor receptor gene transcription by a polymorphic dinucleotide repeat in intron 1. J Biol Chem 274:13176-13180

Pociot F, Molvig J, Wogensen L, Worsaae H, Nerup J (1992) A TaqI polymorphism in the human interleukin-1 beta (IL-1 beta) gene correlates with IL-1 beta secretion in vitro. Eur J Clin Invest 22:396402

Pravica VP, Borreiro LF, Hutchinson IV (1997) Genetic regulation of interferon-gamma production. Biochem Soc Trans 25:176S

Roodman GD (1993) Role of cytokines in the regulation of bone resorption. Calcif Tissue Int 53 (Suppl 1):S94-S98

Rosenwasser LJ, Borish L (1997) Genetics of atopy and asthma: the rationale behind promoter-based candidate gene studies (IL-4 and IL-10). Am J Respir Crit Care Med 156:S152-S155

Sica A, Dorman L, Viggiano V, Cippitelli M, Ghosh P, Rice N, Young HA (1997) Interaction of NF-kappaB and NFAT with the interferon-gamma promoter. J Biol Chem 272:30412-30420

Tsukamoto K, Haruta K, Shiba T, Emi M (1998) Isolation and mapping of a polymorphic CA repeat sequence at the human interleukin 6 locus. J Hum Genet 43:71-72

Tsukamoto K, Emi M (1998) A polymorphic CA repeat sequence at the human calcitonin locus. J Hum Genet 43:146-147

Watanabe I, Tsukamoto K, Shiba T, Emi M (1998) Isolation and radiation hybrid mapping of dinucleotide repeat polymorphism at the human matrix Gla protein (MGP) locus. J Hum Genet 43:75-76 